\title{
The influence of fulvic acid on seed germination and plant productivity
}

Brazienè Z., Paltanavičius V., Avižienytė D.

LRCAF Rumokai Experimental Station, Klausuciai, Lithuania, zita.braziene@lammc.It

Keywords: fulvic acid, seed germination, sugar beet, spring wheat, yield

doi: 10.36291/HIT.2019.braziene.059

Intensive field cultivation technologies cause a degradation of the soil. One of the ways to increase the activity of the soil and the productivity of plants is to use biological preparations and bioorganic fertilizers [1]. Fulvic acid application increase root activity [3], improve growth of plants and yield quantity and quality, limiting the development of some pathogens [2]. Also, fulvic acids improve soil physicochemical conditions [4].

The vegetation and field experiments were conducted in 2017-2018 at the Rumokai Experimental Station of the Lithuanian Research Centre for Agriculture and Forestry. The preparation Mineral Ful (bioactive fulvic acid complex) was used in our experiments.

Fulvic acid increased spring wheat seed germination $6.1 \%$ (Table 1), height of shoots $-2.9 \%$, air-dry mass of shoots $-12.5 \%$, air-dry mass of roots $-22.7 \%$ (Table 2 ) compared to control. Fulvic acid increased the spring wheat grain yield $14.7 \%$, the sugar beet roots yield $-7.9 \%$ (Table 3 ).

Table 1. The influence of fulvic acid and chemical stain on wheat seed germination

\begin{tabular}{lcccc}
\hline Treatment & \multicolumn{2}{c}{ Amount (\%) of } & \multicolumn{2}{c}{$\begin{array}{c}\text { Amount (\%) of } \\
\text { seeds damaged by }\end{array}$} \\
\cline { 2 - 5 } & After 3 days & After 7 days & Fusarium spp. & Monographella nivalis \\
\hline Control & 79.5 & 90.3 & 3.8 & 2.7 \\
\hline Fulvic acid & 87.0 & 95.8 & 1.8 & 2.0 \\
\hline Stain & 43.0 & 92.2 & 1.2 & 1.0 \\
\hline
\end{tabular}

Table 2. The influence of fulvic acid and chemical stain on wheat shoots and roots

\begin{tabular}{lccccc}
\hline Treatment & \multirow{2}{*}{$\begin{array}{c}\text { Shoots } \\
\text { height, } \mathrm{cm}\end{array}$} & \multicolumn{2}{c}{ Mass of shoots, $\mathrm{g}$} & \multicolumn{2}{c}{ Mass of roots, $\mathrm{g}$} \\
\cline { 3 - 6 } & 20.7 & Fresh & Air-dry & Fresh & Air-dry \\
\hline Control & 8.3 & 1.6 & 8.2 & 2.2 \\
\hline Fulvic acid & 21.3 & 9.7 & 1.8 & 11.6 & 2.7 \\
\hline Stain & 15.7 & 8.0 & 1.4 & 9.1 & 2.5 \\
\hline
\end{tabular}

Table 3. The influence of fulvic acid on spring wheat and sugar beets yield

\begin{tabular}{lcccc}
\hline Treatment & & Spring wheat & \multicolumn{2}{c}{ Sugar beet } \\
\hline & $\begin{array}{c}\text { Yield, } \\
\mathrm{t} \mathrm{ha}^{-1}\end{array}$ & $\begin{array}{c}\text { Amount of crude protein, } \\
\%\end{array}$ & $\begin{array}{c}\text { Yield, } \\
\mathrm{t} \mathrm{ha}^{-1}\end{array}$ & $\begin{array}{c}\text { Sugar content, } \\
\%\end{array}$ \\
\hline Control & 2.281 & 9.8 & 89.54 & 15.06 \\
\hline Fulvic acid & 2.616 & 10.5 & 96.58 & 15.30 \\
\hline
\end{tabular}

References

1. Jakienè E., Spruogis V. // Žemès ūkio mokslai. 2015. 22(3):107-120 (In Lithuanian).

2. Moradi P. et al. // J. Centr. Europ. Agric. 2017. 18(3): 584-597.

3. Schmidt W. et al. // In: Hartmann A., Schmid M., Wenzel W., Hinnsinger P. Rhizosphere Perspectives and Challenges, Elsevier. 2004. 1171-1178.

4. Yang et al. Journal of Soil Science and Plant Nutrition. 2013. 13(3):526-533. 